\title{
Peningkatan Kemampuan Guru dalam Memanfaatkan Lingkungan Sekolah Sebagai Sumber Belajar Melalui Bimbingan Individu di SDN 163/X Catur Rahayu Semester Ganjil Tahun Ajaran 2021/2022
}

\author{
Sulastri \\ SDN 163/X Catur Rahayu \\ Desa Catur Rahayu, Kec. Dendang, Kab, Tanjung Jabun, Jambi \\ Sulastri_lastri@gmail.com
}

\begin{abstract}
This research is motivated by the ability of teachers to utilize the environment as a learning resource that needs to be improved. The purpose of this study was to obtain information and discuss about improving the ability of teachers to utilize the school environment as a learning resource through individual guidance at SDN 163/X Catur Rahayu in the odd semester of the 2021/2022 academic year. This type of research is school action research (PTS) which consists of two cycles, where each cycle consists of four stages, namely planning, implementation, observation, and reflection. This research was conducted in the odd semester of the 2021/2022 academic year at SDN 163/X Catur Rahayu with 6 teacher research subjects consisting of class teachers. Data collection techniques using observation sheets and documentation. Data were analyzed using percentages and data reduction. The results showed that through individual guidance can improve the ability of teachers in utilizing the environment as a learning resource at SDN 163/X Catur Rahayu which can be seen in each cycle by giving praise.
\end{abstract}

Keywords: teacher abilities, learning resources, individual guidance

\begin{abstract}
Abstrak
Penelitian ini dilatarbelakangi oleh kemampuan guru dalam memanfaatkan lingkungan sebagai sumber belajar yang perlu untuk ditingkatkan lagi. Tujuan dari penelitian ini adalah untuk mendapatkan informasi dan membahas tentang peningkatan kemampuan guru dalam memanfaatkan lingkungan sekolah sebagai sumber belajar melalui bimbingan individu di SDN 163/X Catur Rahayu semester ganjil tahun ajaran 2021/2022. Jenis penelitian ini adalah penelitian tindakan sekolah (PTS) yang terdiri dari dua siklus, dimana masing-masing siklus terdiri dari empat tahapan yaitu perencanaan, pelaksanaan, observasi dan refleksi. Penelitian ini dilaksanakan pada semester ganjil tahun ajaran 2021/2022 di SDN 163/X Catur Rahayu dengan subjek penelitian guru sebanyak 6 orang yang terdiri dari guru kelas. Teknik pengumpulan data menggunakan lembar observasi dan dokumentasi. Data dianalisis menggunakan persentase dan reduksi data. Hasil penelitian menunjukkan bahwa melalui bimbingan individu dapat meningkatkan kemampuan guru dalam memanfaatkan lingkungan sebagai sumber belajar di SDN 163/X Catur Rahayu yang dapat dilihat pada masing-masing siklus dengan tindakan pemberian pujian
\end{abstract}

Kata kunci: kemampuan guru, sumber belajar, bimbingan individu

Copyright (c) 2021 Sulastri

Corresponding author: Sulastri

Email Address: Sulastri_lastri@gmail.com (Desa Catur Rahayu, Kec. Dendang, Kab, Tanjung Jabun, Jambi)

Received 10 January 2022, Accepted 20 January 2022, Published 16 February 2022

\section{PENDAHULUAN}

Kepala sekolah sebagai salah satu kategori administrator pendidikan perlu melengkapi wawasan kepemimpinan pendidikannya dengan pengetahuan dan sikap yang antisipatif terhadap perubahan yang terjadi dalam kehidupan masyarakat, termasuk perkembangan kebijakan makro pendidikan. Salah satu strategi pembelajaran yang sesuai dengan pakem (pembelajaran aktif, kreatif, efektif dan menyenangkan) sehingga memungkinkan dapat mengembangkan kreativitas, motivasi dan partisipasi siswa dalam pembelajaran adalah dengan memanfaatkan lingkungan sekolah sebagai 
sumber belajar. Hal ini juga sesuai dengan salah satu pilar dari pendekatan kontekstual yaitu masyarakat belajar (learning community). Memanfaatkan lingkungan sekolah sebagai sumber belajar juga sesuai dengan yang disarankan dalam kurikulum 2013 sebagai upaya mendekatkan aktivitas belajar siswa pada berbagai fakta kehidupan sehari-hari di sekitar lingkungannya. Memanfaatkan lingkungan sekolah sebagai sumber belajar menjadi alternatif strategi pembelajaran untuk memberikan kedekatan teoritis dan praktis bagi pengembangan hasil belajar siswa secara optimal. Manfaat nyata yang dapat diperoleh dengan memanfaatkan lingkungan ini adalah: (1) menyediakan berbagai hal yang dapat dipelajari anak, (2) memungkinkan terjadinya proses belajar yang lebih bermakna (meaningful learning), (3) memungkinkan terjadinya proses pembentukan kepribadian anak, (4) kegiatan belajar akan lebih menarik bagi anak, dan (5) menumbuhkan aktivitas belajar anak (learning aktivities). (Badru Zaman, dkk. 2009).

Berkaitan dengan peranan tersebut guru memiliki peranan sebagai pengajar, pendidik, pelatih dan pembimbing untuk mencapai tujuan belajar yang telah direncanakan". Apabila seorang guru dapat melaksanakan proses pembelajaran dengan baik dalam kegiatan pembelajaran, tentunya akan berpengaruh terhadap keberhasilan belajar pada siswa tersebut (Sardiman AM, 2001: 70). Salah satu kemampuan guru yang harus dimiliki oleh guru yaitunya kemampuan dalam menggunakan sumber belajar. Sumber belajar yang tepat akan sangat berguna dan membantu siswa dalam pembelajaran. Berdasarkan hasil observasi yang didapat di SDN 163/X Catur Rahayu. Kemampuan guru dalam menggunakan sumber belajar masih kurang. Diantara sumber velajar yang digunakan yaitu LKS, buku, handout.

Untuk mengatasi masalah di atas maka peneliti mengadakan bimbingan individu terhadap guru-guru di SDN 163/X Catur Rahayu. Bimbingan individu ini diharapkan dapat meningkatkan kemampuan guru-guru dalam menggunakan sumber belajar. Bimbingan individu merupakan bimbngan yang diberikan langsung oleh peneliti sehingga subjek penelitian lebih merasa terbantu dengan adanya bimbingan tersebut.

Berdasarkan permasalahan pada latar belakang di atasa maka peneliti tertarik mengadakan penelitian yang bertujuan untuk mendapatkan informasi dan membahas tentang peningkatan kemampuan guru dalam memanfaatkan lingkungan sekolah sebagai sumber belajar melalui bimbingan individu di SDN 163/X Catur Rahayu semester ganjil tahun ajaran 2021/2022.

Guru adalah salah satu unsur manusia dalam proses pendidikan. Unsur manusia lainnya adalah anak didik. Guru dan anak didik berada dalam satu relasi kejiwaan. Keduanya berada dalam sat interaksi edukatif dengan tugas dan peranan yang berbeda. Undang-Undang Republik Indonesia nomor 14 tahun 2005 tentang Guru dan Dosen menyebutkan bahwa kompetensi adalah seperangkat pengetahuan, keterampilan dan perilaku yang harus dimiliki, dihayati dan dikuasai oleh guru atau dosen dalam melaksanakan tugas keprofesionalannya. Lebih lanjut Robbins (2000) menyatakan bahwa kemampuan terdiri dari 2 faktor, yaitu: 1. Kemampuan intelektual (intelektual ability) 
Merupakan kemampuan melakukan aktifitas secara mental. 2. Kemampuan fisik (Physical ability) Merupakan kemampuan melakukan aktivitas berdasarkan stamina kekuatan dan karakteristik fisik.

Sumber belajar memiliki pengertian yang sangat luas. Sumber belajar menurut Ahmad Rohani \& Abu Ahmadi (1995: 152) adalah guru dan bahan-bahan pelajaran berupa buku bacaan atau semacamnya. Pengertian selanjutnya dari sumber belajar adalah segala daya yang dapat dipergunakan untuk kepentingan proses pembelajaran baik langsung maupun tidak langsung, di luar diri peserta didik yang melengkapi diri mereka pada saat pembelajaran berlangsung. Sumber belajar adalah segala sesuatu yang dapat mendukung proses belajar sehingga memberikan perubahan yang positif. Hal tersebut sesuai dengan pernyataan Arif S Sadiman (dalam Ahmad Rohani \& Abu Ahmadi, 1995: 152153) yang berpendapat bahwa sumber belajar adalah segala macam sumber yang ada di luar yang memungkinkan terjadinya proses belajar.

Sumber belajar adalah segala sesuatu yang dapat memberikan informasi dalam pembelajaran. Abdul Majid (2008:170) mengungkapkan bahwa sumber belajar ditetapkan sebagai informasi yang disajikan dan disimpan dalam berbagai bentuk media, yang dapat membantu siswa dalam belajar, sebagai perwujudan dari kurikulum. Sumber belajar adalah segala sesuatu yang dapat membantu siswa untuk mencapai tujuan pembelajaran. Wina Sanjaya (2010: 175) menyebutkan bahwa sumber belajar adalah segala sesuatu yang dapat dimanfaatkan oleh siswa untuk mempelajari bahan dan pengalaman belajar sesuai dengan tujuan yang hendak dicapai. Sumber belajar disini meliputi, orang, alat dan bahan, aktivitas, dan lingkungan.

Berdasarkan beberapa pendapat ahli di atas dapat disimpulkan bahwa sumber belajar adalah segala sesuatu yang dapat digunakan oleh siswa untuk mempelajari suatu hal. Pengertian dari sumber belajar sangat luas. Sumber belajar tidak terbatas hanya buku saja tetapi dapat berupa, orang, alat, bahan, dan lingkungan yang dapat mendukung proses pembelajaran. Pemanfaatan lingkungan sekolah sebagai sumber belajar mengarahkan anak pada peristiwa atau keadaan yang sebenarnya atau keadaan yang alami sehingga lebih nyata, lebih faktual dan kebenarannya lebih dapat dipertanggungjawabkan. Manfaat nyata yang dapat diperoleh dengan memanfaatkan lingkungan ini adalah: (1) menyediakan berbagai hal yang dapat dipelajari anak, (2) memungkinkan terjadinya proses belajar yang lebih bermakna (meaningful learning), (3) memungkinkan terjadinya proses pembentukan kepribadian anak, (4) kegiatan belajar akan lebih menarik bagi anak, dan (5) menumbuhkan aktivitas belajar anak (learning activities) (Zaman, dkk, 2009).

Pengertian bimbingan yang dikemukakan Abu Ahmadi menunjukkan bahwa dengan adanya layanan bimbingan, siswa diharapkan mengembangkan dirinya dan mampu memahami diri dan lingkungan sekitarnya, untuk mencapai masa depan yang lebih baik. Hal yang senada juga dikemukan Prayitno dan Erman Amti (2004:99) mengenai pengertian bimbingan. "Bimbingan adalah proses pemberian bantuan yang dilakukan oleh orang yang ahli kepada seseorang atau beberapa orang inidividu, baik anak-anak, remaja atau orang dewasa agar orang yang dibimbing dapat mengembangkan kemampuan dirinya sendiri dan mandiri dengan memanfaatkan kekuatan individu 
dan sarana yang ada dan dapat dikembangkan berdasarkan norma-norma yang berlaku". Menurut Rochman Natawidjaja (Juntika Nurihsan, 2006:6) bahwa bimbingan dapat diartikan sebagai suatu proses pemberian bantuan kepada individu yang dilakukan secara berkesinambungan supaya individu tersebut dapat memahami dirinya sendiri, sehinggadia sanggup mengarahkan dirinya dan dapat bertindak secara wajar, sesuai dengan tuntutan dan keadaan lingkungan sekolah, keluarga, masyarakat dan kehidupan pada umumnya.

\section{METODE}

Jenis penelitian ini adalah penelitian tindakan sekolah (PTS) yang terdiri dari dua siklus, dimana masing-masing siklus terdiri dari empat tahapan yaitu perencanaan, pelaksanaan, observasi dan refleksi. Penelitian ini dilaksanakan pada semester ganjil tahun ajaran 2021/2022 di SDN 163/X Catur Rahayu dengan subjek penelitian guru sebanyak 6 orang yang terdiri dari guru kelas. Teknik pengumpulan data menggunakan lembar observasi dan dokumentasi. Data dianalisis menggunakan persentase dan reduksi data.

\section{HASIL DAN DISKUSI}

\section{Siklus I}

\section{Perencanaan}

Pada siklus I peneliti merencanakan langkah-langkah sebagi berikut: 1) Mengidentifikasi jumlah guru yang sudah menggunakan sumber belajar, 2) Meminta guru untuk mengumpulkan sumber belajar, 3) Peneliti memeriksa administrasi guru secara kuantitas dan kulitatif, 4) Peneliti mengidentifikasi permasalahan yang ditemukan, 5) Menyusun rencana tindakan (berupa penjadwalan bimbingan individual disesuaikan dengan temuan pada identifikasi masalah)

\section{Pelaksanaan}

Pelaksanaan pada siklus I dilaksanakan pada hari Senin tanggal 25 Oktober 2021 dan hari Kamis tanggal 28 Oktober 2021. Peneliti selaku kepala sekolah memberi arahan umum pemanfaatan lingkungan sekolah sebagai sumber belajar. Pada tahap ini peneliti melaksanakan rencana tindakan bimbingan individual untuk menilai administrasi guru yang sudah dikumpulkan sebelumnya. Hal ini dilakukan terutama kepada guru yang tidak mengumpulkan perangkat pembelajaran, untuk mengetahui penyebab/masalahnya. Pada pertemuan ini kepala sekolah mengumpulkan 6 orang guru yang menjadi subjek penelitian di ruangan kepala sekolah dan didampingi oleh seorang observer. Kepala sekolah menjelaskan bagaimana cara menggunakan sumber belajar yang baik sehingga dapat membantu proses pembelajaran.

Guru melaksanakan pembelajaran dengan memanfaatkan lingkungan sekolah sebagai sumber belajar sesuai skenario pembelajaran yang dimiliki. Setelah itu kepala sekolah meminta sumber belajar yang digunakan oleh guru selama ini. Setelah itu pertemuan pertama ini dilaksanakan selama 1 jam, guru-guru yang mengajar diminta untuk kembali ke kelas melanjutkan pembelajaran. setelah itu 
dengan hari yang sama kepala sekolah memanggil guru secara individu untuk dibimbing dalam penggunaan dan penyusunan sumber belajar.

Peneliti melakukan penilaian pada guru terkait dengan implementasi pembelajaran sesuai skenario yang dibuat. Setelah semua guru mendapat bimbingan secara individu oleh kepala sekolah, semua sumber belajar yang digunakan oleh guru dikumpulkan oleh kepala sekolah dan dinilai oleh kepala sekolah. Semua sumber belajar dikumpulkan dan dinilai oleh kepala sekolah sesuai dengan indikator penilaian sumber belajar.

\section{Observasi}

Setelah dilaksanakan bimbingan secara individu, peneliti menilai sumber belajar yang digunakan guru sesuai dengan indikator penilaian yaitu kelayakan isi, kelayakan penyajian dan kelayakan bahasa. Untuk lebih jelas dapat dilihat pada tabel berikut ini:

Tabel 1. Penilaian Kemampuan Guru dalam Memanfaatkan Lingkungan Sekolah Sebagai Sumber Belajar Siklus I

\begin{tabular}{|c|c|c|c|c|c|c|}
\hline No & $\begin{array}{l}\text { Aspek yang } \\
\text { dinilai }\end{array}$ & Indikator & Jumlah & $\begin{array}{l}\text { Rata- } \\
\text { Rata }\end{array}$ & $\%$ & Kategori \\
\hline \multirow[t]{4}{*}{1} & \multirow{3}{*}{$\begin{array}{l}\text { Kelayakan } \\
\text { isi }\end{array}$} & Kesesuaian materi & 19 & 3.17 & 79 & \multirow{3}{*}{$\mathrm{B}$} \\
\hline & & Keakuratan materi & 19 & 3.17 & 79 & \\
\hline & & Materi pendukung pembelajaran & 16 & 2.67 & 67 & \\
\hline & \multicolumn{4}{|c|}{ Rata-Rata } & 75 & \\
\hline \multirow[t]{4}{*}{2} & \multirow{3}{*}{$\begin{array}{l}\text { Kelayakan } \\
\text { penyajian }\end{array}$} & Teknik penyajian & 14 & 2.33 & 58 & \multirow[b]{3}{*}{ D } \\
\hline & & penyajian pembelajaran & 13 & 2.17 & 54 & \\
\hline & & Kelengkapan penyajian & 13 & 2.17 & 54 & \\
\hline & \multicolumn{4}{|c|}{ Rata-rata } & 56 & \\
\hline \multirow[t]{4}{*}{3} & \multirow[t]{3}{*}{$\begin{array}{c}\text { Kelayakan } \\
\text { bahasa }\end{array}$} & $\begin{array}{l}\text { Kesesuaian pemakaian bahasa } \\
\text { dengan tingkat perkembangan } \\
\text { siswa }\end{array}$ & 11 & 1.83 & 46 & \multirow{3}{*}{$\mathrm{D}$} \\
\hline & & $\begin{array}{l}\text { Pemakaian bahasa yang } \\
\text { komunikatif }\end{array}$ & 15 & 2.50 & 63 & \\
\hline & & $\begin{array}{l}\text { pemakaian bahasa memenuhi } \\
\text { syarat keruntutan dan } \\
\text { keterpaduan alur berpikir }\end{array}$ & 15 & 2.50 & 63 & \\
\hline & \multicolumn{4}{|c|}{ Rata-Rata } & 57 & \\
\hline
\end{tabular}

Berdasarkan gambar di atas dapat disimmpulkan bahwa kemampuan guru dalam memanfaatkan lingkungan sebagai sumber belajar sumber belajar masih berada pada kategori yang kurang memuaskan sehingga perlu untuk ditingkatkan lagi. Berdasarkan 3 aspek yang dinilai dalam melihat kemampuan guru dalam memanfaatkan lingkungan sebagai sumber belajar didapat bahwa kemampuan guru dalam aspek kelayakan isi berada pada kategori baik (75\%), sedangkan aspek kelayakan penyajian dan kelayakan bahasa berada pada kategori kurang. 
Berikut dijelaskan rekapitulasi hasil penilaian dalam memanfaatkan lingkungan sekolah sebagai sumber belajar oleh masing-masing guru dapat dilihat pada tabel beriku ini:

Tabel 2. Rekapitulasi Hasil Penilaian Sumber Belajar Siklus I

\begin{tabular}{|c|l|c|c|}
\hline No & Nama Guru & $\%$ & Kategori \\
\hline 1 & Sri Wahyuni, S.Pd. SD. & 61 & C \\
\hline 2 & Sutaryo, S.Pd. SD. & 58 & D \\
\hline 3 & Suyitno, S.Pd. SD. & 56 & D \\
\hline 4 & Erfendi, S.Pd. SD. & 64 & C \\
\hline 5 & Agus Assidiq A, S.Pd. & 69 & C \\
\hline 6 & Silvya Nugrahwati, S.Pd. & 67 & C \\
\hline \multicolumn{2}{|c|}{ Rata-Rata } & 63 & C \\
\hline
\end{tabular}

Dari tabel di atas dapat dilihat bahwa dari 6 yang menjadi subjek dalam penelitian ini secara keseluruhan masih berada pada kategoru cukup atau sebesar $63 \%$. 2 orang guru masih berada pada kategori yang kurang memuaskan dan 4 orang guru bearada pada kategori cukup. Hal ini berarti pada siklus I bahwa target yang diharapkan belum tercapai. Untuk itu perlu adanya perbaikan-perbaikan pada siklus berikutnya. Dari tabel di atas dapat disimpulkan bahwa kemampuan guru dalam mengunakan dan menyusun sumber belajar masih rendah dan perlu diadakan perbaikan pada siklus berikutnya.

\section{Refleksi}

Setelah dilakukannya pengamatan, peneliti berdiskusi dengan observer yang dilaksanakan pada hari Sabtu tanggal 30 Oktober 2021 Suratmin, S.Pd. dan bertempat di ruangan kepala SDN 163/X Catur Rahayu. Dari hasil pengamatan dapat dilihat bahwa masih adanya kelemahan-kelemahan yang di dapat pada siklus I. Diantaranya masih ada guru yang menyusun dan menggunakan sumber belajar tanpa memperhatikan indikator-indikator penulisan dan penggunaan sumber belajar. Untuk itu, peneliti dan kolaborator berdiskusi untuk memecahkan masalah tersebut agar tidak terjadi lagi pada siklus II. Pada siklus II peneliti berusaha mengurangi kekurangan-kekurangan yang ada pada siklus I yaitu dengan memberikan tindakan reward bagi guru yang menyusun dan menggunakan sumber belajar sesuai dengan indikator-indikator yang ditetapkan. Untuk itu penelitian ini dilanjutkan ke siklus II. Hasil refleksi ini dijadikan acuan untuk merencanakan penyempurnaan dan perbaikan siklus berikutnya. Semua tahap kegiatan tersebut mulai dari tahap perencanaan, pelaksanaan maupun observasi dan evaluasi dilakukan secara berulang-ulang melalui siklus-siklus sampai ada peningkatan sesuai yang diharapkan yaitu mencapai angka katagori "baik" dengan rentang skor 80 - 89. Jika skor yang diperoleh kurang dari $80-89$, berarti belum memenuhi target yang ditetapkan, maka perlu bimbingan pada siklus II.

\section{Siklus II}

\section{Perencanaan}

Tahap perencanaan siklus II terdiri dari: 1) Peneliti berkoordinasi dengan kepala sekolah untuk menyampaikan materi penelitian dan minta masukan tentang masalah yang ada sekaligus 
membicarakan masalah teknis, waktu pelaksanaan penelitian untuk siklus II, 2) Bersama kepala sekolah menyiapakna materi bimbingan untuk siklus II, 3) Peneliti mengidentifikasi permasalahan yang ditemukan, 4) Menyusun rencana tindakan (berupa penjadwalan bimbingan individual disesuaikan dengan temuan pada identifikasi masalah)

\section{Pelaksanaan}

Tahap pelaksanaan siklus II dilaksanakn pada hari Senin tanggal 8 November 2021 dan hari Kamis tanggal 11 November 2021 di SDN 163/X Catur Rahayu. Dengan memperhatikan hasil refleksi antara peneliti bersama kepala sekolah dan guru, peneliti berkesimpulan perlunya untuk mengadakan perbaikan dalam tindakan pembimbingan terhadap guru. Dengan harapan akan terjadi peningkatan kemampuan guru dalam menyusun dan menggunakan sumber belajar. Atas dasar hasil penelitian nampak bahwa kegiatan pembimbingan sebagai tugas pokok kepala sekolah sangat diperlukan. Hal ini diakui oleh para guru karena untuk memenuhi kebutuhan guru, terutama dalam meningkatkan mutu pembelajaran yang merupakan tugas utama guru diperlukan adanya bantuan profesional dari kepala sekolah. Para guru menyadari bahwa mereka merasa belum optimal dalam upaya memberdayakan pembelajaran. Karena itu mereka berharap adanya pembinaan yang terus menerus agar mereka dapat mengelola kegiatan pembelajaran secara optimal.

Pada siklus II ini peneliti melanjutkan penyampai materi tentang penyusunan sumber belajar. Selanjutnya, seperti diberitahukan sebelumnya bahwa pada siklus II ini guru diminta untuk mempraktekkan lagi penggunaan sumber belajar pada saat bimbingan intensif guna memperbaiki hasil yang didapat pada siklus I. Untuk itu pada siklus II ini guru sudah mempersiapkan berbagai sumber belajar yang dapat digunakan dalam proses belajar mengajar.

Melalui bimbingan, guru mendiskusikan tentang permasalahan-permasalahann atau hambatan memanfaatkan lingkungan sekolah sebagai sumber belajar, dalam menyusun skenario pembelajaran yang selanjutnya dicarikan pemecahannya. Kegiatan ini dibantu oleh guru yang dianggap sudah cukup mampu dalam hal tersebut. Guru mempresentasikan dan mensimulasikan hasil diskusi serta merevisi dan juga menyempurnakan skenario pembelajaran dengan mengoptimalkan pemanfaatan lingkungan sekolah sebagai sumber belajar. Selanjutnya pada pertemuan berikutnya guru melaksanakan kegiatan belajar mengajar di kelas dengan menggunakan skenario pembelajaran yang sudah direvisi. Guru mendiskusikan dan menyempurnakan skenario pembelajaran yang lengkap dengan pemanfaatan lingkungan sekolah sebagai sumber belajar. Guru mencatat kekurangan pembelajaran yang perlu diperbaiki dan disempurnakan.

\section{Observasi}

Berdasarkan hasil pengamatan yang dilakukan oleh peneliti dan dibantu oleh seorang kolaborator maka dapat dilihat pada tabel berikut ini: 
Tabel 3. Penilaian Kemampuan Guru dalam Memanfaatkan Lingkungan Sekolah Sebagai Sumber Belajar Siklus II

\begin{tabular}{|c|c|c|c|c|c|c|}
\hline No & $\begin{array}{l}\text { Aspek yang } \\
\text { dinilai }\end{array}$ & Indikator & Jumlah & $\begin{array}{l}\text { Rata- } \\
\text { Rata }\end{array}$ & $\%$ & Kategori \\
\hline \multirow[t]{4}{*}{1} & \multirow{3}{*}{$\begin{array}{l}\text { Kelayakan } \\
\text { isi }\end{array}$} & Kesesuaian materi & 23 & 3.83 & 96 & \multirow{4}{*}{ A } \\
\hline & & Keakuratan materi & 19 & 3.50 & 88 & \\
\hline & & $\begin{array}{l}\text { Materi pendukung } \\
\text { pembelajaran }\end{array}$ & 16 & 3.67 & 92 & \\
\hline & \multicolumn{4}{|c|}{ Rata-Rata } & 92 & \\
\hline \multirow[t]{4}{*}{2} & \multirow{3}{*}{$\begin{array}{l}\text { Kelayakan } \\
\text { penyajian }\end{array}$} & Teknik penyajian & 20 & 3.33 & 83 & \multirow{4}{*}{ A } \\
\hline & & penyajian pembelajaran & 19 & 3.17 & 79 & \\
\hline & & Kelengkapan penyajian & 20 & 3.33 & 83 & \\
\hline & \multicolumn{4}{|c|}{ Rata-rata } & 82 & \\
\hline \multirow[t]{4}{*}{3} & \multirow[t]{3}{*}{$\begin{array}{c}\text { Kelayakan } \\
\text { bahasa }\end{array}$} & $\begin{array}{l}\text { Kesesuaian pemakaian } \\
\text { bahasa dengan tingkat } \\
\text { perkembangan siswa }\end{array}$ & 18 & 3.00 & 75 & \multirow{4}{*}{ B } \\
\hline & & $\begin{array}{l}\text { Pemakaian bahasa yang } \\
\text { komunikatif }\end{array}$ & 18 & 3.00 & 75 & \\
\hline & & $\begin{array}{l}\text { pemakaian bahasa } \\
\text { memenuhi syarat } \\
\text { keruntutan dan keterpaduan } \\
\text { alur berpikir }\end{array}$ & 20 & 3.33 & 83 & \\
\hline & \multicolumn{4}{|c|}{ Rata-Rata } & 78 & \\
\hline
\end{tabular}

Berdasarkan gambar di atas dapat disimmpulkan bahwa kemampuan guru dalam menyusun dan menggunakan sumber belajar masih berada pada kategori yang sangat memuaskan. Dari 3 indikator penilaian terhadap kemampuan guru dalam memanfaatkan lingkungan sebagai sumber belajar didapat bahwa aspek kelayakan isi yang disampaikan oleh guru berada pada kategori sangat baik sebesar $92 \%$, aspek kelayakan penyajian berada pada kategori sangat baik sebesar $82 \%$, dan aspek kelayakan bahasa berada pada kategori baik sebesar 78\%. Secara keseluruhan kemampuan guru dalam memanfaatkan lingkungan sebagai sumber belajar sudah berada pada kategori sangat baik, tentunya ini untuk kedpannya perlu ditingkatkan terus. Berikut dijelaskan rekapitulasi hasil penilaian dalam memanfaatkan lingkungan sekolah sebagai sumber belajar oleh masing-masing guru dapat dilihat pada tabel berikut ini:

Tabel 4. Rekapitulasi Hasil Penilaian Sumber Belajar Siklus II

\begin{tabular}{|r|l|c|c|}
\hline No & Nama Guru & $\%$ & Kategori \\
\hline 1 & Sri Wahyuni, S.Pd. SD. & 81 & A \\
\hline 2 & Sutaryo, S.Pd. SD. & 89 & A \\
\hline 3 & Suyitno, S.Pd. SD. & 81 & A \\
\hline 4 & Erfendi, S.Pd. SD. & 86 & A \\
\hline 5 & Agus Assidiq A, S.Pd. & 83 & A \\
\hline 6 & Silvya Nugrahwati, S.Pd. & 83 & A \\
\hline \multicolumn{2}{|c|}{ Rata-Rata } & 84 & A \\
\hline
\end{tabular}


Dari tabel di atas dapat dilihat bahwa dari 4 orang guru sudah berada pada kategori yang sangat memuaskan. Hal ini berarti pada siklus I bahwa target yang diharapkan sudah tercapai. Untuk itu perlu adanya perbaikan-perbaikan pada siklus berikutnya. Hal ini dapat dilihat dari persentase ketuntasan yang diperoleh oleh guru. Untuk itu penelitian dianggap telah mencapai target yang ditargetkan.

\section{Refleksi}

Tahap refleksi siklus II dilaksanakan pada hari Sabtu tangal 13 November 2021 dengan dibant oleh seorang observer yang bernama Suratmin, S.Pd. bertempat di ruangan kepala SDN 163/X Catur Rahayu. Data yang terkumpul diolah secara kuantitatif (persentase) dan secara kualitatif (prediket). Dari refleksi ini akan tergambar hasil yang telah dicapai pada proses tindakan yang telah dilakukan. Pada bagian refleksi ini masalah-masalah yang ditemukan pada siklus I sudah teratasi di siklus II dan tidak perlu lagi dilanjutkan ke siklus berikutnya. Pada tahap refleksi ini peneliti melakukan diskusi untuk membahas hasil penelitian yang didapat pada siklus II. Berdasarkan hasil observasi didapat bahawa pada siklus II target yang diiginkan sudah tercapai dengan memberikan tindakan pemberian pujian. Untuk itu dikarenakan penelitian ini telah berhasil maka tidak dilanjutkan ke siklus berikutnya. Berdasarkan hasil penilaian terhadap kemampuan guru dalam menggunakan sumber belajar dan pengamatan terhadap guru dalam kegiatan pembelajaran dapat direfleksi dan dievaluasi dapat disampaikan bahwa selama proses kegiatan bimbingan individu para guru merasakan manfaat yang sangat banyak, terutama pengalaman yang selama ini jarang mereka lakukan dalam pengelolaan pembelajaran. Suasana pembelajaran juga terasa sangat mengasikkan, bukan saja bagi siswa melainkan para guru juga merasakan hal yang sama.

\section{Diskusi}

Berdasarkan hasil penelitian dapat diketahui bahwa melalui Bimbingan individu di SDN 163/X Catur Rahayu guru mampu memanfaatkan lingkungan sebagai sumber belajar saat proses belajar mengajar berlangsung. Pembimbingan atau pembinaan guru sering diartikan sebagai serangkaian usaha bantuan kepada guru, terutama yang berwujud layanan professional yang dilakukan oleh kepala sekolah, pengawas sekolah atau pembina lainnya untuk meningkatkan proses dan hasil belajar (Hamzah,2007:169). Proses pembelajaran yang berhasil guna memerlukan teknik, metode, dan pendekatan tertentu sesuai dengan karakteristik tujuan, peserta didik, materi, dan sumber daya. Sehingga diperlukan strategi yang tepat dan efektif. Menurut Joni (1992) strategi pembelajaran merupakan suatu seni dan ilmu untuk membawa pembelajaran sedemikian rupa sehingga tujuan yang telah ditetapkan dapat dicapai secara efesien dan efektif dalam (Depdiknas,2010:7).

\section{KESIMPULAN}

Berdasarkan hasil penelitian dan pembahasan didapat kesimpulan bahwa melalui bimbingan individu dapat meningkatkan kemampuan guru dalam memanfaatkan lingkungan sebagai sumber 
belajar di SDN 163/X Catur Rahayu yang dapat dilihat pada masing-masing siklus dengan tindakan pemberian pujian.

Berdasarkan hasil penelitian yang diperoleh, dapat disarankan beberapa hal, antara lain: 1) Kepada para Pengawas sekolah disarankan agar dalam melaksanakan tugasnya membina guru menggunakan serta mengembangkan supervisi akademik sebagai wahana untuk peningkatan kemampuan pedagogik guru, 2) Kepada guru agar bekerja sama dengan Pengawas serta Kepala sekolah dalam rangka meningkatkan kinerja dan profesionalismenya, 3) Bagi pengambil kebijakan di lingkungan Dinas Pendidikan disarankan untuk menjadikan hasil penelitian ini sebagai salah satu alternatif dalam meningkatkan kemampuan guru yang berdampak terhadap peningkatan mutu pendidikan.

\section{REFERENSI}

A, Cece. Wijaya. (1991). Kemampuan Dasar Guru Dalam Proses Belajar. Mengajar. Bandung: PT Remaja Rosda karya.

Abdul Majid. (2006). Perencanaan Pembelajaran. Bandung: PT Remaja. Rosdakarya.

Abdul Majid. (2008). Perencanaan Pembelajaran, Mengembangkan Standar. Kompetensi Guru. Jakarta: PT. Rosda Karya

Abu Ahmadi \& Ahmad Rohani. (1991). Bimbingan dan Konseling di Sekolah. Jakarta: PT Rineka Cipta.

Amti, Erman dan Prayitno. (2004). Layanan bimbingan dan konseling kelompok. Padang: Jurusan Bimbingan dan Konseling Fakultas Ilmu Pendidikan.

Badru Zaman, dkk. (2009). Media dan Sumber Belajar. Jakarta: Universitas Terbuka.

John M. Hassan Shadily. (1984). Kamus Inggris Indonesia. Jakarta: Gramedia

Juntika, dkk. (2010). Landasan Bimbingan dan Konseling. Bandung: PT. Remaja Rosdakarya

Muslich, Mansur. (2010). Textbook Writing. Jakarta: Ar-Ruzz Media

Nana Sudjana. (1989). Dasar-Dasar Proses Belajar Mengajar. Bandung: Angkasa

Raka Joni, T. (1992). Peningkatan Mutu Pendidikan Dasar dan Menengah $\quad$ Melalui $\quad$ Strategi Pembelajaran Aktif(Cara Belajar Aktif) dan pembinaan Profesional Guru, Kepala Sekolah, Penilik dan Pengawas Sekolah Serta Pembina Lainnya. Jakarta: Debdikbud.

Robbins. (2000). Keterampilan Dasar. Jakarta: PT Raja Grafindo.

Sanjaya, Wina. (2010). Strategi Pembelajaran Berorientasi Standar Proses. Pendidikan. Jakarta: Prenada Media Group

Sardiman. (2001). Interaksi dan Motivasi Belajar Mengajar. Jakarta: Raja. Grafindo Persada.

Siregar, Eveline \& Hartini Nara. (2014). Teori Belajar dan Pembelajaran. Bogor: Galia Indonesia.

Suryosubroto. (1997). Proses Belajar Mengajar Di Sekolah. Jakarta: PT. Rineksa Cipta

Undang-Undang RI Nomor 14 Tahun 2005 Bab IV pasal 8 ayat (1) tentang Guru dan Dosen. 
Peningkatan Kemampuan Guru dalam Memanfaatkan Lingkungan Sekolah Sebagai Sumber Belajar Melalui Bimbingan Individu di SDN 163/X Catur Rahayu Semester Ganjil Tahun Ajaran 2021/2022, Sulastri

Uno, Hamzah B. (2007). Model Pembelajaran Menciptakan Proses Belajar.Mengajar yang Kreatif dan Efektif. Jakarta: Bumi Aksara

Windura, Susanto. (2008). Mind Map Langkah Demi Langkah. Jakarta: Gramedia. 